\title{
THE IMPACTS OF COUNTRY-OF-ORIGIN, PRODUCT INVOLVEMENT, AND PRODUCT FAMILIARITY ON PRODUCT EVALUATION
}

\author{
Sahid Susilo Nugroho, Rokhima Rostiani \& Indriyo Gitosudarmo \\ Universitas Gadjah Mada \\ (sahid@ugm.ac.id)
}

\begin{abstract}
One of the most interesting phenomena in global business is the existence of a product's country-of-origin (COO). COO as an informational cue has been proven to affect consumer's purchasing decisions in terms of their perception towards the product's attributes as well as their overall evaluation of the product. The objective of this study is to investigate the impacts of country-of-origin on product evaluation in the Indonesian market by considering consumers' product familiarity and consumers' product involvement. Consumers' perception of the product's country-of-origin is assumed to have a significant influence on consumers' considerations in evaluating the product prior to purchase. This impact is supposedly moderated by the extent that consumers are familiar with the product's attributes and to what extent the product is important and interesting to them. A survey design was employed to test the proposed linkages among the variables.

The target population of the survey was Indonesian consumers of imported products. The sample unit is the person who has experience in buying or consuming foreign products. The sample of 307 persons was drawn from Yogyakarta. This study examined televisions to represent a high involvement product. The country stimuli are Korea and Indonesia. The study applied the regression analyses and hierarchical moderated regression to test the proposed hypotheses. The study found that: (1) Indonesian consumers associate positively a product's country-of-origin with their decision in evaluating the product for both Indonesian and Korean products, (2) Indonesian consumers consider the level of economic development of the countryof-origin in evaluating the product, in which the effect of the country-of-origin is stronger for a Korean product than an Indonesian product, (3) Indonesian consumers with different levels of product familiarity do not evaluate a product differently for both Indonesian and Korean products, (4) Indonesian consumers with different levels of product involvement evaluate a Korean product differently.
\end{abstract}

Keywords: country-of-origin, product evaluation, Korea, TV Product

\section{INTRODUCTION}

The globalization of business has not only inspired companies to deliver their products and services to consumers all over the world, but also stimulated a higher degree of competition in the global market. One of the most interesting phenomena in global business practices is the existence of a product's country-of-origin (COO). The COO, which is one typically important attribute of every international brand, stands for the country to which people believe a product comes from (Anholt, 2000). The COO as an informational cue has been proven to affect consumer's purchasing decisions in terms of their perception towards the product's attributes as well as their overall evaluation of the product.

The benefit of using a COO strategy is the existence of that country's image, since sometimes consumers already have a relationship with, or opinions about, different countries. Consumers develop stereotypical beliefs about products from certain countries. For instance, Germany is well known for manufacturing high quality automobiles, Japan for electronic products, and Italy for food and fashion products. Therefore, the COO serves as a supporting factor 
to any product that has little chance of being marketed internationally on its own (Kleppe et al., 2002). The strong image of the country-oforigin in terms of its competitive and, or comparative advantage is assumed to enhance the quality of the products.

Consumers' perceptions of similar products, or even identical brands, may vary depending upon the country where the products are made. For example, some consumers think that Nikon cameras made in Japan are superior to those made in China, since Japan is perceived to be a country with better craftsmanship than China has. However, nowadays, it is relatively difficult to identify from which country the product originally comes from since the creation of multinational or global companies having crossborder production and marketing activities. In that way, they produce a hybrid product, which may be designed in one country, assembled in another country with components that are sourced in several other countries (Ahmed \& d'Astous, 1995, p.35).

Regarding a hybrid product, consumers still think that the first country producing a product is perceived to be the product's country-of-origin. For example, most Indonesian consumers think that Sony's electronic products are still Japanese products, even though Sony already assembles its products in Indonesia. In this case, the country-of-design is perceived to be stronger than the country-of-origin, regardless of which country the product is actually made or assembled in. This phenomenon is summarized in the definition of the COO based on Chao and Rajendran's study (1993). They pointed out that consumers perceive the product to originate from the country with which the firm is most closely associated with, regardless of where the product may actually be produced. This definition does not view the $\mathrm{COO}$ as a unidimensional concept, which defines the $\mathrm{COO}$ as the only country where the product is made. Instead, it adopts a multidimensional concept by distinguishing the COO into the country-of-design and country-ofassembly (Ahmed \& d'Astous, 1995). Thus, the $\mathrm{COO}$ can be identified from the country-ofdesign or country-of-assembly depending on which country is more closely associated with the product.

Consumers in developing countries consider the $\mathrm{COO}$ as a status-enhancing symbol in addition to suggesting overall quality. There are some explanations why the $\mathrm{COO}$ phenomena is stronger in developing countries (Batra et al., 2000). First, imported products in developing countries are both relatively expensive and limited in quantity compared to local products. Therefore, only rich consumers can buy the imported products, which therefore become more desirable to those without adequate purchasing power. Second, consumers in developing countries are sensitive to insecurity and inferiority, since they are relatively less affluent than those in developed countries, as represented by mostly western countries. Thus, they try to imitate western countries' consumption practices by purchasing a foreign brand as a symbol of an affluent western lifestyle. Third, the willingness to show their competence in relating to alien cultures works as one of the main motivational factors behind the emergence of "cosmopolitan" consumers in developing countries. The possession of imported products is perhaps the only way they can demonstrate that competence. Finally, since not every consumer in developing countries can access imported products, the product, which becomes a symbol of status, affluence, and modernity, can enhance their social status. The more they consume imported products, the higher the social status they get.

In term of product evaluation, consumers usually use the $\mathrm{COO}$ as a surrogate indicator to measure the quality levels of the products especially when they are not really familiar with the product. To some extent, consumers with a good education, good income, high familiarity toward foreign products, or international experience accept foreign products and have a more positive attitude toward imported products (Anderson \& Cunningham, 1972). When consumer evaluate the product on the basis of its $\mathrm{COO}$, it can be assumed that they consider themselves familiar with the country. Therefore, it is perhaps very difficult for consumers who are not well 
informed about the country to use the COO cue to evaluate the product (Johansson, 1989).

In evaluating a product, consumers usually care about the quality of the product when they think the product is important or interesting to them. This situation encourages them to be more involved in evaluating the product in terms of their time and costs searching for information about the product (high involvement product). In contrast, when the product is perceived to be not important or interesting to the consumers, they do not want to spend a lot of effort to evaluate it (low involvement product). Consumers perhaps do not really care about the country-of-origin when they want to buy certain low involvement products.

Among the high involvement product categories available in the Indonesia marketplace, certain electronic products, especially TVs from Asian manufacturers are on the rise. Korean brand TVs, of which Samsung and LG are the main players, and who possess a high market share and growth in the global marketplace, are prevalent. According to the data from an industry analyst, DisplaySearch, in 2011 Samsung had cemented its position as the global leader in plasma and LCD TVs followed by LG in second place. The Japanese brands Panasonic, Sony, and Sharp occupied the next positions. The popularity of Korean products is probably enhanced by the spreading Korean pop music phenomenon (K-Pop) over the world. The surge of K-Pop has begun to attract the interest of the global media, allowing Korea to enjoy a considerable spotlight on its cultural frontiers. In Indonesia, people started to favor not only K-Pop, but also Korean cars, electronics, cosmetics and fashion products.

Along with the growing popularity of Korean culture in the world, several multinationals from Korea now enjoy a better position in the global marketplace. A survey conducted by the Korea Trade-Investment Promotion Agency (KOTRA) in 2012 found that there are favorable responses to the image of "Made in Korea" products and services. The rise of the national brand through culture has led to an increase in preference for Korean products and services as well. Global consumers' perceived price level for Korean electronics has enjoyed a 10.3 point increase compared to its 2006 level, when KOTRA began to release the annual report on the nation brand map.

\section{PROBLEM DEFINITION}

Based on previous research findings (Batra et al., 2000), it can be inferred that consumers in developing countries such as Indonesia are considered to be very sensitive to COO effects. Thus, the impact of the $\mathrm{COO}$ on product evaluation tends to be stronger. Therefore, the study also aims to confirm whether the $\mathrm{COO}$ effect on product evaluation for Indonesian consumers is also strong. It is also proposed that there will be differences between the $\mathrm{COO}$ evaluation on national brands (Indonesia) and foreign brands (Korea) by Indonesian consumers. The study contributes new insights in terms of both theoretical and practical contexts. As mentioned by Phau and Prendergast (Phau \& Prendergast, 2000), most COO studies have concentrated on high involvement products. The research findings are important to enrich discussions on the research topic of country-of-origin by proposing product involvement as an additional strong relevant factor beside product familiarity.

\section{RESEARCH QUESTIONS}

Four research questions can be specified to address proposed linkages among variables as follows:

- Does the country-of-origin positively influence product evaluation?

- Does a more developed country-of-origin have a stronger effect on product evaluation than a less developed country-of-origin?

- Does product familiarity moderate the effect of the country-of-origin on product evaluation?

- Does product involvement moderate the effect of the country-of-origin on product evaluation?

\section{RESEARCH PURPOSE}

The purpose of this study is to investigate the impacts of a product's country-of-origin on the 
evaluation of the product in the Indonesian market by considering consumers' product involvement and consumers' product familiarity. The study will use TVs produced in Indonesia and Korea for its comparison. Consumers' perceptions of the country where the product comes from is assumed to have a significant influence on consumers' considerations in evaluating the product prior to purchase. This influence is supposedly moderated by the extent that consumers are familiar with the product's attributes and to what extent the product is important and interesting to them.

\section{LITERATURE REVIEW AND HYPOTHESES}

\section{Product Evaluation}

Product evaluation is one stage of the buying decision process (Kotler, 2003). In this stage, consumers try to evaluate the best product among the available alternatives. There are decision evaluation processes, which assume the evaluation process to be cognitively oriented as consumers form their judgments mainly on a conscious and rational basis. To choose among competing products, consumers may face difficulties in assessing product performance and quality. A common response from consumers when they are asked to define quality is "I cannot define quality but I know it when I see it." (Hansen \& Bush, 1999). This fact illustrates that the meaning of quality may vary depending on personal differences. Every individual has his or her own way to define the quality of a product.

Previous studies showed that the perceived quality of products would vary depending on consumer perceptions of both the intrinsic and extrinsic marketing cues associated with the product (Bhuian, 1997). A cue is defined as a characteristic, event, quality or object, external to a person, that can be encoded and used to categorize a stimulus object (Schellink, 1983, p. 470). Examples of cues are color, size, price, brand name, style, and country-of-origin (COO). Any object that can be associated with numerous potential cues will result in different perceptions and interpretations among different individuals and situations. Therefore, it is important to cate- gorize and describe cues in order to study the determinants of choice among the different types of cue.

Olson (Rao \& Monroe, 1989) pointed out that consumers might use a variety of informational cues to infer product quality. Based on previous studies, the cues consist of extrinsic cues such as the brand name (e.g. Dodds et al., 1991; Jacoby, Szybillo \& Busato-Schah, 1977; Peterson \& Jolibert, 1976), price (e.g. Dodds et al., 1991; Weathley et al., 1981; Woodside, 1974) and the country-of-origin (e.g. Han \& Tepstra, 1988; Chao, 1989a, 1989b) which are not related directly to the product's performance. On the other hand, intrinsic cues such as materials, contents, ingredients and packaging are derived directly from the physical product. Compared to intrinsic cues, extrinsic cues are more general and applicable to a wider range of products, whereas intrinsic cues are more specific to a particular product.

Additionally, Lee and Lou (1995) concluded that consumers are generally more familiar with extrinsic cues such as the brand name, price, and country-of-origin than intrinsic cues. Thus, consumers are likely to rely more heavily on extrinsic cues when evaluating products. This is supported by Dawar \& Parker (1994) who argued that in the situation wherein neither infinite time horizons nor the incentive to perform comprehensive comparative assessment prior to purchase exists, consumers tend to rely only on heuristic cues as a cognitive short cut to gauge product quality by using extrinsic cues. It may be caused by several factors: (1) there is a need to reduce the perceived risk of purchase, (2) the consumers lacks expertise and consequently the ability to assess quality, (3) consumer involvement is low, (4) objective quality is too complex to assess or the consumer is not in the habit of spending time objectively assessing quality, (5) there is an information search preference and need for information.

\section{Product Evaluation and Country-of-Origin}

Although academic research into country-oforigin started over 30 years ago, so far, there is no one acceptable definition of country-of-origin 
(COO). The oldest definition of $\mathrm{COO}$ is as follows:

"The 'made in' image is the picture, the reputation, and the stereotype that businessmen and consumers attach to products of a specific country. This image is created by such variables as representative products, national characteristic, economic and political background, history, and traditions." (Nagashima, 1970)

That definition deduces that the $\mathrm{COO}$ is an extrinsic cue of the product like the brand name or price, which serves as informational stimulus used by consumers to infer beliefs regarding the product quality. Additionally, those definitions assume that the product is designed and manufactured in the same country. However, nowadays, it is very complicated to identify from which country the product originates. The existence of multinational or global companies having cross-border production and marketing activities enables them to produce a hybrid product, which may be designed in one country, assembled in another country with components that are sourced in several other different countries (Ahmed \& d'Astous, 1995).

Therefore, the definition of the COO variable used in this study will be based on Chao and Rajendran's study (1993 that viewed the COO as the consumers' perception that generally assumes that the product originates from the country with which the firm is closely associated, regardless of where the product may actually be produced. This definition does not view the $\mathrm{COO}$ as a unidimensional concept, which defines the $\mathrm{COO}$ as the only country where the product is made. Instead, it adopts a multidimensional concept by distinguishing the $\mathrm{COO}$ into country-of-design and country-ofassembly (Ahmed \& d'Astous, 1995). Thus, the $\mathrm{COO}$ can be identified from the country-ofdesign or the country-of-assembly, depending on which country is more closely associated with the product. The country-of-origin construct is conceived from the idea in which people attached stereotypical "made-in" perceptions to products from specific countries, and which influenced purchase and consumption behaviors in multinational markets.

\section{The Effect of Country-of-Origin on Product Evaluation}

To handle complex processing tasks in evaluating the competitive products prior to their purchase, consumers often consider only a few of the multiple attributes of the intended product. By considering a few of attributes, such as the country-of-origin (COO), they attempt to ease the cognitive processing required in their decision making processes (Johansson, 1989). In the process of product evaluation, the $\mathrm{COO}$ label eases the utilization of a mental "short-cut" or heuristic approach to eliminate unnecessary information processing since the $\mathrm{COO}$ provides a brief summary of the actual attributes of a product (surrogate variable). Therefore, the $\mathrm{COO}$ allows consumers to save time and effort in evaluating a product (Verlegh, 2002). However, the impact of the $\mathrm{COO}$ on product evaluation decreases when the consumer's ability to process information has increased (Maheswaran, 1994). As consumers gain access to a greater number of cues such as the brand, price, technical specifications, and after sales service, the role of one particular cue, such as the $\mathrm{COO}$, in influencing product evaluation is expected to decrease.

Kleppe et al. (2002) explained the work of the $\mathrm{COO}$ cue in the process of consumers' product evaluation. They pointed out that the $\mathrm{COO}$ can be viewed as a structure of knowledge in consumers' minds with varied associations of a certain country in terms of uniqueness, favoritism, strength and salience. Those associations, which are called country-related intangible assets (Kim \& Chung, 1997), consist of technical advancement, prestige, workmanship, innovativeness, design, economy and service owned by the country. Those associations arise from the consumers' belief that there is something special about them in relationship with the labor forces, technologies, and manufacturing processes involved in producing the product. This image of the COO has a substantial impact on judgments of product evaluation (Kleppe et al., 2002). When consumers think that the country-of-origin 
of the product has a positive image, it will lead to a positive result in the product evaluation. A positive result means that the product is considered to be of good quality as well as have a high purchase value, and to stimulate consumers' willingness to buy it. The following hypothesis is suggested to address this issue.

$\mathrm{H}_{1}$ : A positive image of the country-of-origin will be positively associated with a positive result of the product evaluation.

Amine and Shin (2002) proposed that the $\mathrm{COO}$ effect on product evaluation in signaling the quality of the product is not absolute for a given country, but it is different for different countries. Their findings indicate that the $\mathrm{COO}$ effect on product evaluation tends to be stronger in the developing countries than it is in the developed countries. This result perhaps is influenced by a common myth about the COO, that the products made in developed countries must be of better quality than those made in developing countries. Furthermore, a study by Manrai et al. (1998), which proposed a hierarchy of effects based on the level of economic development, suggested that perceived quality tends to be highest for products sourced in highly-developed countries, followed by newly-industrialized countries, and lowest for Eastern European/ socialist countries as well as developing countries. The next hypothesis is proposed to examine this issue.

$\mathrm{H}_{2}$ : Country-of-origin from a more developed country has a stronger effect on the product evaluation than country of origin from a less developed country.

\section{Effect of Product Familiarity in the Relationship between $\mathrm{COO}$ and Product Evaluation}

In term of product evaluation, Park and Lessig (1981) proposed two approaches to define product familiarity. The first approach is actual knowledge or how much a person knows about the product. What he actually knows about a product may be derived from some objective training or advertising. According to this view, product familiarity may be examined with respect to the knowledge structure of an individual's long-term memory. The second approach is perceived knowledge or how much a person thinks he knows about the product. What the person thinks he or she knows about a product may come from using the product. However, this knowledge perhaps is not objective and complete since it depends simply on his or her experiences in using the product. Referring to this view, product familiarity is based on the person's self report of how much the person knows about the product. The former approach contributes to understanding the impact of memory content on the decision maker's evaluation and choice decisions, whereas the latter approach provides information about decision maker' systematic biases and heuristics in choice evaluations and decisions.

Previous studies have shown that such extrinsic cues as the brand name, price and country-of-origin have a significant effect on product evaluation (e.g. Dodds et al., 1991; Han \& Tepstra, 1988; Chao, 1989a: Chao, 1989b). It happens since consumers are obviously more familiar with extrinsic cues than with intrinsic cues. Bettman and Park (1980) supported this argument by pointing out that consumers who are more familiar with a certain product category tend to rely on brand name in their product evaluation and choice processes. They concluded that product knowledge is likely to be brand based wherein consumers with more knowledge tend to use the brand as the basis for their product evaluations. On the other hand, consumers who are less familiar with the product category will evaluate specific attributes of the product, and then integrate their evaluations to reach an overall judgment. For example, unfamiliar consumers perhaps measure the quality of products based on their price or country-oforigin as surrogate indicators due to their lack of knowledge. In terms of price, they think that the higher the price, the better the quality is.

Similarly, in term of the country-of-origin, they perceive that products originating from developed countries must be better than those from developing countries. In addition, Han (1989) explained how product familiarity could 
influence the use of the country-of-origin to evaluate the product. Han classified the effects into two models. First, when consumers are not familiar with a country's products, the $\mathrm{COO}$ will serve as a halo from which consumers infer a brand's product attributes and which affects their attitude toward the brand indirectly through the product's attribute rating. Second, as consumers become familiar with a country's products, country image becomes a summary of consumers' beliefs about the product's attributes and directly affects their attitude toward the brand. It means that product familiarity will strengthen the impact of the country of origin on the product evaluation. The following hypothesis is proposed to address this issue.

$\mathrm{H}_{3}$ : Product familiarity moderates the effect of the country-of-origin on product evaluation.

\section{Effect of Product Involvement in the Relationship between COO and Product Evaluation}

There is still little agreement among researchers on how to define the construct of involvement due to the different applications of the term involvement. Zaichkowsky (1985a) suggested that involvement could be related to such different objects as advertisement, product category, or purchase decision wherein every object will lead to a different response. In terms of purchase decisions, involvement will lead consumers to search for more information and spend more time searching for the right selection. This means that the more involved the consumers are, the more information and time they need to make their purchasing decision.

Kapferer and Laurent (1986) found that in marketing, involvement is defined as perceived product importance (e.g. Agostini, 1978; Traylor, 1981; Lastovicka \& Bonfield, 1982). However, this definition is in doubt due to its narrow perspective compared to the richness of the involvement relationship. This argument is supported by the study of Hansen (1985) that disagreed with the former definition by describing involvement as the consumer's interest in a product category. Hansen hypothesized that a consumer may think that a television set is important without being involved, when he or she has no interest in that equipment.

Despite differences of opinion among researchers, a consensus emerged as to the following generic definition of involvement from Rothschild (Kapferer \& Laurent, 1986, p. 49): "Involvement is an unobservable state of motivation, arousal or interest. It is evoked by a particular stimulus or situation and has drive properties. Its consequences are types of searching, information-processing and decision making."

Korgaonkar and Moschis (Zaichkowsky, 1986) used a factor of differentiation of alternatives as a primary discriminator of high and low involvement products. For example, the degree of substitution with brands and differences in performance are used to classify soft drinks as low-involving products and radios as highinvolving products. The question under study is whether high-involving products or low-involving products are evaluated differently after receiving positive or negative information about the product.

The research findings show that a high involvement product is less vulnerable to changes in evaluation after consumers receive discrepant information, than the low involvement product is. The logic underlining this result is that, under high involvement conditions, beliefs about the product's attributes are firmly held by consumers and only influenced by strong, quality arguments, whereas under a low involvement condition, beliefs are not strongly held and are easily manipulated (Zaichkowsky, 1986).

Studies investigating the effects of the country-of-origin on product evaluation have focused mainly on higher involvement goods such as cars and electronic equipment (Alden et al, 1993). Meanwhile, low involvement goods are rarely evaluated prior to purchase. For most low involvement purchasing decisions, consumers tend to rely on a few salient and extrinsic features such as the brand name, price, or countryof-origin which activate generalizations from memory about the product category and brand reputation (Alden et al., 1993). This means that 
product involvement will weaken the impact of the country of origin on the product evaluation. The next hypothesis is raised to examine this concern.

$\mathrm{H}_{4}$ : Product involvement moderates the effects of the country-of-origin on product evaluation.

\section{The Research Model}

The research model can be summarized as that consumers' perception of the country the product comes from is assumed to give a significant impact to the outcome of the product evaluation prior to purchasing. This influence is supposedly moderated by product involvement and product familiarity. The study, therefore, will measure an independent variable of the country-of-origin (COO) and two moderating variables of product involvement and product familiarity in relationship to one dependent variable of product evaluation. The relationship model among the independent variables, moderating variable and dependent variable is drawn in Figure 1.

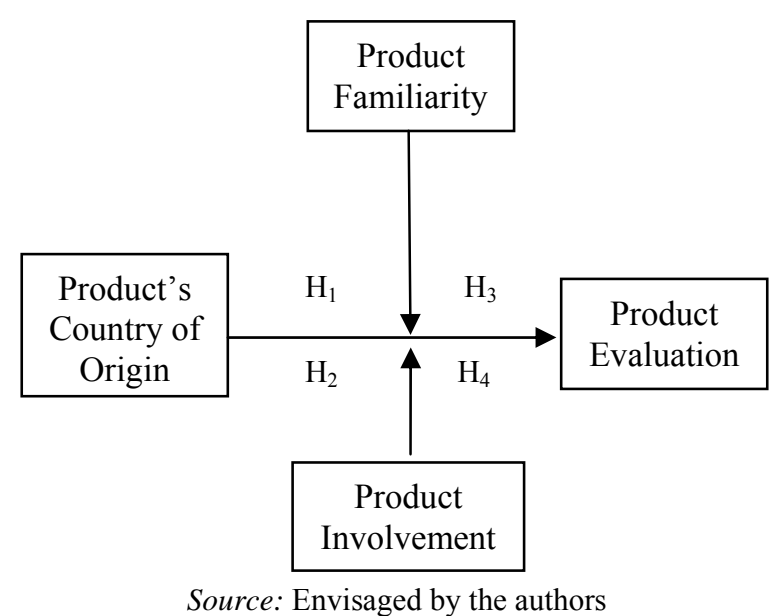

Figure 1. Research Model

\section{RESEARCH METHOD}

A survey design was employed to test the proposed linkages among variables. This study uses Korean (Samsung and LG) and Indonesian (Polytron) LED Televisions as the study objects. The target population is the Indonesian consumer of imported products. The sample unit is the person who has experience in buying or con- suming imported products. The samples are drawn from residents of the special province of Yogyakarta (Daerah Istimewa Yogyakarta). This research site is believed to cover the Indonesian consumer population of imported products since it has a heterogeneous population consisting of various Indonesian races.

Respondents were selected based on their occupations by a quota sampling method. The study used seven occupational groups to classify the respondents as follows: (1) house wife, (2) high school students, (3) university students, (4) operational workers, (5) managerial workers, (6) professional, and (7) businessmen.

A close-ended questionnaire consisting of 41 items was used as the survey instrument to collect the data. All questionnaires were distributed directly to the respondents to ensure a high response rate. 315 questionnaires were distributed and all were returned to the researcher. However, only 307 questionnaires were used for data analysis due to some having incomplete responses. Data collection were conducted in universities, schools, offices, malls, and stores in Sleman and Yogyakarta as both areas comprises of urban lifestyle respondents that were targeted for this research.

\section{MEASUREMENT}

Product evaluation is one stage of the buying decision process (Kotler, 2003). In this stage, consumers try to evaluate the best product among available alternatives before purchasing one of them. Product evaluation has evaluative dimensions of perceived quality and perceived value, and intention dimension of willingness to buy (Petroshius \& Monroe, 1987). Therefore, product evaluation is measured using three subproperties:

1) Perceived quality is defined as the consumer's perception on how well a product meets his or her needs.

2) Perceived value is defined as the consumer's perception of the worth of a product in term of value of money.

3) Willingness to buy is defined as the consumer's intention to buy the product. 
The COO is an extrinsic cue of the product, like its brand name or price that serves as informational stimulus used by consumers to infer beliefs regarding the product quality. The $\mathrm{COO}$ variable used in this study is based on consumers' perceptions assuming that the product originates from the country with which the firm is closely associated, regardless of where the product may actually be produced (Chao \& Rajendran, 1993). COO is measured using four sub-properties developed from the study of Darling and Kraft (1991):

1) Innovativeness or consumers' perception of the use of new technologies and engineering advances in products made in a certain country.

2) Design or consumers' perception of the appearance, style, color, variety of products made in a certain country.

3) Prestige or consumers' perception of the exclusivity, status and brand name reputation of products made in a certain country.

4) Workmanship or consumers' perception of the reputation of reliability, durability craftsmanship, and manufacturing quality in general of products made in a certain country.

Park and Lessig (1981) proposed two approaches to define product familiarity as actual knowledge or how much a person knows about the product, and perceived knowledge or how much a person thinks he knows about the product. What the person thinks he or she knows about a product may come from using the product. What he actually knows about a product may be derived from some objective training or advertising. Product familiarity is measured using two sub-properties:

1) Consumer's actual knowledge or what the consumer actually knows about a product. It may be derived from objective training, advertising or word-of-mouth.

2) Consumer's perceived knowledge or what the person thinks he or she knows about a product. It may come from his or her experience in using the product.

Notwithstanding differences of perspective among researchers, broad acceptance is given to the following generic definition of involvement from Rothschild (Kapferer \& Laurent, 1986): "Involvement is an unobservable state of motivation, arousal or interest. It is evoked by a particular stimulus or situation and has drive properties. Its consequences are types of searching, information-processing and decision making."

A review of experimental manipulations of involvement (e.g. Festinger, 1957; Zimbardo, 1960; Greenwald \& Leavitt, 1984; Park \& Young, 1984) of marketing studies and manager's opinions revealed that involvement has five antecedents. It could stem from one or from a combination of the five following antecedents: interest, perceived risk (with two subcomponents, importance and probability), the rewarding nature of the product (pleasure value), and the perceived ability of brand choice to express one's status and one's personality or identity (Kapferer \& Laurent, 1986). Therefore, product involvement is assessed using five sub-properties developed from the study of Kapferer and Laurent (1986):

1) Interest or centrality, ego-importance of the product class.

2) Pleasure or hedonic and rewarding value of the product class.

4) erceived sign value of the product class.

5) Risk importance or perceived importance of the negative consequences of a mistaken purchase.

6) Risk probability or subjective probability of making a mistaken purchase.

All variables are measured by 7 likely Likert scales in which the centre scale of neutral is hidden due to the strong tendency of Indonesian people to be conservative in judging the evaluation. The scales start from Strongly disagree (valued as 1) until Strongly agree (valued as 7).

\section{DATA QUALITY EXAMINATION}

The study attempted to assess the construct validity of both the independent and dependent variables prior to analyzing the data. The study applied two methods to assess the construct validity: (1) content validity and (2) convergent validity. Content validity is assessed by 
conforming to the relevant concepts and theories. Convergent validity is measured using an confirmatory factor analysis. Average variance extracted (AVE) indicators are also calculated to support that validity evaluation. As shown in Table 1, not all measurement items can pass the validity test.

AVE indicators show that product familiarity $(\mathrm{PF})$ is the only variable that has a unsatisfied score (below 0.5). Whereas, all variables have satisfying reliability performances as indicated by Cronbach Alpha scores that are above 0.6. Therefore, the study is still convinced the data are good, and so used the data for further analysis. Additional evaluations, that is a normality test, is applied to examine the data quality. As shown in Table 1 , since all K-S indicators are significant. Therefore it confirms that all data are not normally distributed.

Table 1. Data Quality Examination

\begin{tabular}{|c|c|c|c|c|c|c|c|}
\hline Variable & Items & $\begin{array}{l}\text { Factor } \\
\text { Loading }\end{array}$ & Mean & $\begin{array}{c}\text { Standard } \\
\text { Deviation }\end{array}$ & AVE & $\begin{array}{l}\text { Cronbach } \\
\text { Alpha }\end{array}$ & $\begin{array}{l}\text { Kolmogorov- } \\
\text { Smirnov Test } \\
\text { Z (Sig.) }\end{array}$ \\
\hline \multirow{4}{*}{$\begin{array}{l}\text { Product } \\
\text { Involvement } \\
\text { (PI) }\end{array}$} & PI 1 & 0,582424948 & \multirow{4}{*}{3.4039} & \multirow{4}{*}{0.9311} & \multirow{4}{*}{0.5401} & \multirow{4}{*}{0.794} & \multirow{4}{*}{0.64} \\
\hline & PI 2 & 0,786104887 & & & & & \\
\hline & PI 3 & 0,824675675 & & & & & \\
\hline & PI 4 & 0,723357705 & & & & & \\
\hline \multirow{5}{*}{$\begin{array}{l}\text { Product Familiarity } \\
\text { (PF) }\end{array}$} & PF 12 & 0,688381274 & \multirow{5}{*}{3.4228} & \multirow{5}{*}{0.9661} & \multirow{5}{*}{0.4581} & \multirow{5}{*}{0.877} & \multirow{5}{*}{0.10} \\
\hline & PF 13 & 0,719232573 & & & & & \\
\hline & PF 14 & 0,723864942 & & & & & \\
\hline & PF 16 & 0,595202158 & & & & & \\
\hline & PF 17 & 0,649264015 & & & & & \\
\hline \multirow{4}{*}{$\begin{array}{l}\text { Indonesian } \\
\text { Product's Country } \\
\text { of Origin } \\
\text { (CI) }\end{array}$} & CI 18 & 0,750442763 & \multirow{4}{*}{3.1963} & \multirow{4}{*}{0.7477} & \multirow{4}{*}{0.5279} & \multirow{4}{*}{0.744} & \multirow{4}{*}{0.01} \\
\hline & CI 19 & 0,729988478 & & & & & \\
\hline & CI 21 & 0,694101125 & & & & & \\
\hline & CI 23 & 0,730603738 & & & & & \\
\hline \multirow{4}{*}{$\begin{array}{l}\text { Indonesian Product } \\
\text { Evaluation (PEI) }\end{array}$} & PEI 26 & 0,778910524 & \multirow{4}{*}{3.3656} & \multirow{4}{*}{0.7775} & \multirow{4}{*}{0.5552} & \multirow{4}{*}{0.836} & \multirow{4}{*}{0.00} \\
\hline & PEI 27 & 0,719689056 & & & & & \\
\hline & PEI 28 & 0,691295041 & & & & & \\
\hline & PEI 29 & 0,786506736 & & & & & \\
\hline \multirow{7}{*}{$\begin{array}{l}\text { Korean Product's } \\
\text { Country of Origin } \\
\text { (CK) }\end{array}$} & CK 30 & 0,772760673 & \multirow{7}{*}{3.3616} & \multirow{7}{*}{1.0059} & \multirow{7}{*}{0.5381} & \multirow{7}{*}{0.925} & \multirow{7}{*}{0.02} \\
\hline & CK 31 & 0,789916759 & & & & & \\
\hline & CK 32 & 0,780150409 & & & & & \\
\hline & CK 33 & 0,800341936 & & & & & \\
\hline & CK 34 & 0,786719343 & & & & & \\
\hline & CK 35 & 0,500361162 & & & & & \\
\hline & CK 36 & 0,653699531 & & & & & \\
\hline \multirow{4}{*}{$\begin{array}{l}\text { Korean Product } \\
\text { Evaluation (PEK) }\end{array}$} & TEK 38 & 0,781808643 & & & & & \\
\hline & TEK 39 & 0,841678744 & & & & & \\
\hline & TEK 40 & 0,822773306 & 3.5554 & 1.0466 & 0.6881 & 0.931 & 0.00 \\
\hline & TEK 41 & 0,869565085 & & & & & \\
\hline
\end{tabular}

Source: Primary data (2014) 


\section{HYPOTHESES TESTING}

\section{The First Hypothesis}

The first hypothesis addresses the relationship between the country-of-origin (COO) and the product evaluation. Customers' positive perceptions of the country-of-origin (COO) of the product they want to buy is hypothesized to have an association with a positive product evaluation (PE). As shown in Table 2 and Table 3, the results of regression analysis of both Indonesian and Korean TVs prove that the relationship between the $\mathrm{COO}$ and $\mathrm{PE}$ are significant $(p<0.05)$, and have a positive direction as represented by the positive values of $\beta=0.396$ and $\beta=0.772$ for Indonesian and Korean TVs respectively. Based on this finding, therefore, the study accepts the first hypothesis since the study confirmed that a positive $\mathrm{COO}$ could be positively associated with the product evaluation.

This finding shows that Indonesian consumers use the COO label to simplify the complex processing tasks in evaluating products prior to purchasing. The COO label facilitates a mental "short-cut" to eliminate unnecessary information processing by providing a brief summary of the actual attributes of a product. Positive associations with country-related intangible assets (Kim \& Chung, 1997) such as technical advancement, prestige, workmanship, innovativeness, design, economy and service, lead to a positive result of product evaluation. It means that the product is considered to be of good quality as well as having a high purchase value, and to stimulate consumers' willingness to buy it. Hence, it can be concluded that Indonesia and Korea have positive country images as country-of-origins for televisions.

\section{The Second Hypothesis}

The second hypothesis addresses the different effects of country-of-origin (COO) on product evaluation (PE) resulting from different levels of economic development of the country the product comes from. When a product comes from a more developed country, consumers tend to have a more positive product evaluation than when it comes from a less developed country. The results of regression analysis, as revealed in Table 2 and Table 3, present that the effect of the country-of-origin becomes stronger when the product comes from a more developed country. The values of standardized regression weight $(\beta)$, which represent the effect of the COO on PE in the case of more developed countries, are higher than those in the case of less developed countries.

Table 2. Regression Analysis of Indonesia TVs

\begin{tabular}{ccccccc}
\hline \multirow{2}{*}{ Model } & & \multicolumn{2}{c}{$\begin{array}{c}\text { Unstandardized } \\
\text { Coefficients }\end{array}$} & $\begin{array}{c}\text { Standardized } \\
\text { Coefficients }\end{array}$ & $\mathrm{t}$ & Sig. \\
\cline { 3 - 7 } & & \multicolumn{1}{c}{ B } & Std. Error & Beta & B & Std. Error \\
\hline \multirow{2}{*}{1} & (Constant) & 2,049 &, 179 & & 11,420 &, 000 \\
& CI &, 412 &, 055 &, 396 & 7,533 &, 000 \\
\hline
\end{tabular}

a Dependent Variable: PEI

Source: Primary data (2014)

Table 3. Regresion Analysis of Korean TVs

\begin{tabular}{|c|c|c|c|c|c|c|}
\hline \multirow[t]{2}{*}{ Model } & & \multicolumn{2}{|c|}{$\begin{array}{c}\text { Unstandardized } \\
\text { Coefficients }\end{array}$} & \multirow{2}{*}{$\begin{array}{c}\begin{array}{c}\text { Standardized } \\
\text { Coefficients }\end{array} \\
\text { Beta } \\
\end{array}$} & \multirow{2}{*}{$\begin{array}{l}\mathrm{t} \\
\mathrm{B}\end{array}$} & \multirow{2}{*}{$\frac{\text { Sig. }}{\text { Std. Error }}$} \\
\hline & & $\mathrm{B}$ & Std. Error & & & \\
\hline \multirow[t]{2}{*}{1} & (Constant) &, 854 & ,133 & & 6,432 &, 000 \\
\hline & $\mathrm{CK}$ & ,804 & ,038 & ,772 & 21,242 &, 000 \\
\hline
\end{tabular}

a Dependent Variable: PEK

Source: Primary data (2014) 
The value of $\beta$ coefficient of Korean TVs (0.772) is higher than that of Indonesian TVs (0.396). Based on these findings, therefore, the study accepts the second hypothesis since the study proved that the level of economic development of the country the product comes from differentiate the effect of the COO on PE. To evaluate the product, Indonesian consumers consider the level of economic development of the product's country-of-origin. This finding supports the previous study (Batra et al., 2000), it can be inferred that consumers in developing countries such as Indonesia are considered to be sensitive to COO effects. Thus, the impact of the $\mathrm{COO}$ on product evaluation tends to be stronger.

\section{The Third Hypothesis}

The third hypothesis focuses on the role of product familiarity $(\mathrm{PF})$ in moderating the effect of the country-of-origin (COO) on product evaluation (PE). The usage of the $\mathrm{COO}$ information by consumers to evaluate the product they want to buy is more likely made by consumers with low and high product familiarity than by consumers with moderate familiarity (Rao \& Monroe, 1988).

The results of hierarchical moderated regression (HMR) analysis, as shown in Tables $4 \mathrm{~b}$ and $5 \mathrm{~b}$ respectively, present that the $\mathrm{F}$ change between the full model and the restricted model of both Indonesian and Korean TVs are not significant. In the case of Indonesian TVs, $\alpha=$ $0.133(>0.05)$ with $\mathrm{R}$ square change minus 0.006 . Whereas in the case of Korean TVs, $\alpha=$ $0.078(>0.05)$ with $\mathrm{R}$ square change minus 0.004. Based on these findings, therefore, the study rejects the third hypothesis since the PF does not moderate the effect of the $\mathrm{COO}$ on the PE. These results do not support the previous study ( Rao \& Monroe, 1998) who concluded that the usage of extrinsic cues such as the $\mathrm{COO}$ in product evaluation is more likely made by unfamiliar consumers and also highly-familiar consumers.

\section{The Fourth Hypothesis}

The fourth hypothesis addresses the role of product involvement in moderating the effects of the country-of-origin (COO) on product evaluation (PE). The previous studies show that under high involvement conditions, beliefs about the product's attributes are firmly held by consumers and only influenced by strong highquality arguments. Meanwhile, under low involvement conditions, beliefs are not so strongly held and are easily manipulated (Zaichkowsky, 1986). Since consumers tend to rely on extrinsic cues such as the $\mathrm{COO}$ that activate generalizations from memory about the product category and brand reputation (Alden et al., 1993). Therefore, the $\mathrm{COO}$ is likely used by lowly involved consumers rather than by highly involved consumers.

Using the results of hierarchical moderated regression (HMR) analyses to test the fourth hypothesis, Table $6 \mathrm{~b}$ presents that the $\mathrm{F}$ change between the full model and the restricted model of Indonesian TVs was not significant with $\alpha=0.909 \quad(>0.05)$ and no $R$ square change. However, as shown in Table $7 \mathrm{~b}$, a positive result was scored by Korean TVs. They had $\alpha=0.000$ $(<0.05)$ and $\mathrm{R}$ square change minus 0.017 .

Therefore, the study accepts the fourth hypothesis only in the case of Korean TVs. Since PI moderates the effect of CK on PEK. Based on this result, it can be assumed that to some extent, Indonesian consumers with any different level of product involvement do not use the $\mathrm{COO}$ as an extrinsic cue in evaluating the product prior to purchase. This finding supported the study of Zaichkowsky (1986) as well as the study of Alden et al. (1993) as described previously. 
Table 4a. The Hierarchical Moderated Regression Analysis of Indonesian TVs to Examine the Moderating Effect of Product Familiarity

\begin{tabular}{llcccccc}
\hline \multirow{2}{*}{ Model } & & \multicolumn{2}{c}{ Unstandardized Coefficients } & Standardized Coefficients & $\mathrm{t}$ & Sig. \\
\cline { 3 - 7 } & & \multicolumn{1}{c}{$\mathrm{B}$} & Std. Error & Beta & $\mathrm{B}$ & Std. Error \\
\hline 1 & (Constant) & 1,650 &, 527 & & 3,130 &, 002 \\
& RITCI &, 778 &, 172 &, 748 & 4,519 &, 000 \\
& RITPF &, 010 &, 156 &, 012 &, 064 &, 949 \\
& RITCIRITPF &,- 071 &, 047 &,- 444 & $-1,506$ &, 133 \\
2 & (Constant) & 2,392 &, 188 & & 12,738 &, 000 \\
& RITCI &, 534 &, 059 &, 514 & 9,090 &, 000 \\
& RITPF &,- 215 &, 045 &,- 269 & $-4,756$ &, 000 \\
3 & (Constant) & 2,049 &, 179 & & 11,420 &, 000 \\
& RITCI &, 412 &, 055 &, 396 & 7,533 &, 000 \\
\hline
\end{tabular}

a Dependent Variable: RITEI

Source: Primary data (2014)

Table 4b. The HMR Model Summary of Indonesian TVs for Product Familiarity

\begin{tabular}{ccccccccccc}
\hline \multirow{2}{*}{ Model } & \multirow{2}{*}{$\mathrm{R}$} & \multirow{2}{*}{$\mathrm{R}$} & \multirow{2}{*}{$\begin{array}{c}\text { Adjusted R } \\
\text { Square }\end{array}$} & $\begin{array}{c}\text { Std. Error of the } \\
\text { Square }\end{array}$ & Estimate & $\begin{array}{c}\text { R Square } \\
\text { Change }\end{array}$ & $\begin{array}{c}\text { Change Statistics } \\
\text { Change }\end{array}$ & df1 & df2 & $\begin{array}{c}\text { Sig. F } \\
\text { Change }\end{array}$ \\
\hline 1 &, $470(\mathrm{a})$ &, 221 &, 213 &, 68966 &, 221 & 28,665 & 3 & 303 &, 000 \\
2 &, $464(\mathrm{~b})$ &, 215 &, 210 &, 69110 &,- 006 & 2,267 & 1 & 303 &, 133 \\
3 &, $396(\mathrm{c})$ &, 157 &, 154 &, 71517 &,- 058 & 22,616 & 1 & 304 &, 000 \\
\hline
\end{tabular}

a Predictors: (Constant), RITCIRITPF, RITCI, RITPF

b Predictors: (Constant), RITCI, RITPF

c Predictors: (Constant), RITCI

Source: Primary data (2014)

Table 5a. The Hierarchical Moderated Regression Analysis (PF) of Korean TVs to Examine the Moderating Effect of Product Familiarity

\begin{tabular}{llccccc}
\hline \multirow{2}{*}{ Model } & & \multicolumn{2}{c}{ Unstandardized Coefficients } & Standardized Coefficients & t & Sig. \\
\cline { 3 - 7 } & & $\mathrm{B}$ & Std. Error & Beta & $\mathrm{B}$ & Std. Error \\
\hline 1 & (Constant) &,- 222 &, 413 & &,- 538 &, 591 \\
& KTCK &, 868 &, 140 &, 835 & 6,208 &, 000 \\
& KTPF &, 484 &, 125 &, 446 & 3,877 &, 000 \\
& KTCKKTPF &,- 066 &, 037 &,- 378 & $-1,770$ &, 078 \\
& (Constant) &, 464 &, 143 & & 3,251 &, 001 \\
& KTCK &, 635 &, 046 &, 610 & 13,720 &, 000 \\
& KTPF &, 280 &, 048 &, 258 & 5,811 &, 000 \\
& (Constant) &, 854 &, 133 & & 6,432 &, 000 \\
& KTCK &, 804 &, 038 &, 772 & 21,242 &, 000 \\
\hline
\end{tabular}

a Dependent Variable: KTEK

Source: Primary data (2014) 
Table 5b. The HMR Model Summary of Korean TVs for Product Familiarity

\begin{tabular}{cccccccccc}
\hline \multirow{2}{*}{ Model } & \multirow{2}{*}{$\mathrm{R}$} & \multirow{2}{*}{$\mathrm{R}$} & \multicolumn{2}{c}{ Adjusted } & Std. Error of & \multicolumn{5}{c}{ Change Statistics } \\
\cline { 6 - 11 } & & Square & R Square & the Estimate & & & \\
\hline 1 &, $800(\mathrm{a})$ &, 641 &, 637 &, 63043 &, 641 & 180,117 & 3 & 303 &, 000 \\
2 &, $798(\mathrm{~b})$ &, 637 &, 635 &, 63264 &,- 004 & 3,133 & 1 & 303 &, 078 \\
3 &, $772(\mathrm{c})$ &, 597 &, 595 &, 66575 &,- 040 & 33,767 & 1 & 304 &, 000 \\
\hline
\end{tabular}

a Predictors: (Constant), KTCKKTPF, KTPF, KTCK

b Predictors: (Constant), KTPF, KTCK

c Predictors: (Constant), KTCK

Source: Primary data (2014)

Table 6a. The Hierarchical Moderated Regression Analysis of Indonesian TVs to Examine the Moderating Effect of Product Involvement

\begin{tabular}{ccccccc}
\hline \multirow{2}{*}{ Model } & & \multicolumn{2}{c}{ Unstandardized Coefficients } & Standardized Coefficients & $\mathrm{t}$ & Sig. \\
\cline { 3 - 7 } 1 & & $\mathrm{~B}$ & Std. Error & Beta & $\mathrm{B}$ & Std. Error \\
& (Constant) & 1,670 &, 628 & & 2,657 &, 008 \\
& RITCI &, 413 &, 198 &, 397 & 2,080 &, 038 \\
& RITPI &, 129 &, 169 &, 143 &, 766 &, 444 \\
& RITCIRITPI &,- 006 &, 052 &,- 032 &,- 114 &, 909 \\
2 & (Constant) & 1,737 &, 223 & & 7,780 &, 000 \\
& RITCI &, 391 &, 055 &, 376 & 7,106 &, 000 \\
& RITPI &, 111 &, 048 &, 123 & 2,323 &, 021 \\
3 & (Constant) & 2,049 &, 179 & & 11,420 &, 000 \\
& RITCI &, 412 &, 055 &, 396 & 7,533 &, 000 \\
\hline
\end{tabular}

a Dependent Variable: RITEI

Source: Primary data (2014)

Table 6b. The HMR Model Summary of Indonesian TVs for Product Involvement

\begin{tabular}{|c|c|c|c|c|c|c|c|c|c|}
\hline \multirow[b]{2}{*}{ Model } & \multirow[b]{2}{*}{$\mathrm{R}$} & \multirow[b]{2}{*}{$\begin{array}{c}\mathrm{R} \\
\text { Square }\end{array}$} & \multirow[b]{2}{*}{$\begin{array}{l}\text { Adjusted } \\
\text { R Square }\end{array}$} & \multirow[b]{2}{*}{$\begin{array}{l}\text { Std. Error of the } \\
\text { Estimate }\end{array}$} & \multicolumn{5}{|c|}{ Change Statistics } \\
\hline & & & & & $\begin{array}{l}\text { R Square } \\
\text { Change }\end{array}$ & F Change & df1 & $\mathrm{df} 2$ & $\begin{array}{l}\text { Sig. F } \\
\text { Change }\end{array}$ \\
\hline 1 &, $414(a)$ & , 172 & , 163 &, 71123 & , 172 & 20,922 & 3 & 303 & ,000 \\
\hline 2 & ,414(b) & ,172 & , 166 & ,71007 & ,000 & ,013 & 1 & 303 & ,909 \\
\hline 3 &, $396(\mathrm{c})$ & 157 & , 154 & ,71517 &,- 015 & 5,396 & 1 & 304 & 021 \\
\hline
\end{tabular}

a Predictors: (Constant), RITCIRITPI, RITPI, RITCI

b Predictors: (Constant), RITPI, RITCI

c Predictors: (Constant), RITCI 
Table 7a. The Hierarchical Moderated Regression Analysis of Korean TVs to Examine the Moderating Effect of Product Involvement

\begin{tabular}{clrccccc}
\hline \multirow{2}{*}{ Model } & & \multicolumn{2}{c}{ Unstandardized Coefficients } & Standardized Coefficients & \multicolumn{1}{c}{ t } & Sig. \\
\cline { 3 - 7 } & & \multicolumn{1}{c}{ B } & Std. Error & Beta & \multicolumn{1}{c}{ B } & Std. Error \\
\hline \multirow{2}{*}{1} & (Constant) & $-1,126$ &, 432 & & $-2,605$ &, 010 \\
& KTCK & 1,234 &, 134 & 1,186 & 9,207 &, 000 \\
& KTPI &, 634 &, 124 &, 564 & 5,107 &, 000 \\
& KTCKKTPI &,- 138 &, 037 &,- 711 & $-3,779$ &, 000 \\
2 & (Constant) &, 391 &, 164 & & 2,393 &, 017 \\
& KTCK &, 748 &, 039 &, 719 & 19,359 &, 000 \\
& KTPI &, 191 &, 042 &, 170 & 4,574 &, 000 \\
3 & (Constant) &, 854 &, 133 & & 6,432 &, 000 \\
& KTCK &, 804 &, 038 &, 772 & 21,242 &, 000 \\
\hline
\end{tabular}

a Dependent Variable: KTEK

Source: Primary data (2014)

Table 7b. The HMR Model Summary of Korean TVs to Examine the Moderating Effect of Product Involvement

\begin{tabular}{|c|c|c|c|c|c|c|c|c|c|}
\hline \multirow[b]{2}{*}{ Model } & \multirow[b]{2}{*}{$\mathrm{R}$} & \multirow[b]{2}{*}{ R Square } & \multirow[b]{2}{*}{$\begin{array}{l}\text { Adjusted } \\
\text { R Square }\end{array}$} & \multirow{2}{*}{$\begin{array}{l}\text { Std. Error of } \\
\text { the Estimate }\end{array}$} & \multicolumn{5}{|c|}{ Change Statistics } \\
\hline & & & & & $\begin{array}{c}\text { R Square } \\
\text { Change }\end{array}$ & $\begin{array}{c}\mathrm{F} \\
\text { Change }\end{array}$ & df1 & df2 & $\begin{array}{l}\text { Sig. F } \\
\text { Change }\end{array}$ \\
\hline 1 &, $800(a)$ & 640 & ,636 & ,63138 & ,640 & 179,276 & 3 & 303 & ,000 \\
\hline 2 & ,789(b) & 623 & ,620 & ,64502 &,- 017 & 14,282 & 1 & 303 & ,000 \\
\hline 3 &, $772(\mathrm{c})$ & ,597 & ,595 & 66575 &,- 026 & 20,923 & 1 & 304 & ,000 \\
\hline
\end{tabular}

a Predictors: (Constant), KTCKKTPI, KTPI, KTCK

b Predictors: (Constant), KTPI, KTCK

c Predictors: (Constant), KTCK

Source: Primary data (2014)

\section{DISCUSSIONS}

Based on the research findings, the study can make several final conclusions. First, Indonesian consumers positively associate the country-oforigin $(\mathrm{COO})$ of the product with their decision in evaluating the product prior to purchase. A positive perception of the $\mathrm{COO}$ leads to a positive product evaluation. To some extent, it is consistent with the study of Verlegh and Steenkamp (1999), the cognitive mechanism is perceived to work among Indonesian consumers. They tend to use the $\mathrm{COO}$ as a signal for overall product quality and quality attributes. It is used to simplify the complex processing tasks in evaluating products prior to purchasing. Positive associations with country-related intangible assets: technical advancement, prestige, workmanship, innovativeness, design, economy and service, lead to a positive result for the product evaluation. The product is considered to be of good quality as well as have a high purchase value, and to stimulate consumers' willingness to buy. Hence, Indonesia and Korea have positive country images as the COOs of televisions.

Second, in the cases of televisions, Indonesian consumers consider the level of economic development of the $\mathrm{COO}$ in evaluating the product prior to purchase. The products from developed countries such as Korea are considered to be better than those from developing countries such as Indonesia. Since Indonesian consumers apparently behave rationally in evaluating the product by giving a higher preference to imported products that usually have a high social status symbol for Indonesian people. This conclusion supports the study of Manrai et al. 
(1998) that proposed a hierarchy of effects of the $\mathrm{COO}$ based on the level of its economic development, since the product's $\mathrm{COO}$ is associated with the best technical standards for quality (Maheswaran, 1994). The validity of this research finding is also justified in terms of the research method. To overcome the lack of product object realism (e.g. Bilkey \& Nes, 1982; Schooler, 1971), this study used multiple cues in which the COO was not the only information on which respondents made their evaluations. Other extrinsic and intrinsic cues relevant to the products such as the price, brand, features, and packaging were also shown to them. Respondents could comprehensively and objectively evaluate every tested product since those other influent cues are included in the properties of the $\mathrm{COO}$ variable.

Third, Indonesian consumers with different levels of product familiarity do not behave differently when using the $\mathrm{COO}$ information on their product evaluation. The study indicated that with both Indonesian and Korean TVs, product familiarity did not moderate the effect of the $\mathrm{COO}$ information on the product evaluation.

Fourth, Indonesian consumers with different levels of product involvement evaluate product differently after receiving information about the $\mathrm{COO}$ only in the case of the Korean TVs. Since product involvement moderates the effect of the $\mathrm{COO}$ information on product evaluation, therefore it supported the study of Zaichkowsky (1986) and Alden et al. (1993), which pointed out that the $\mathrm{COO}$ is more likely used by lowly involved consumers rather than by highly involved consumers.

\section{REFERENCES}

Ahmed, S.A. \& A. d'Astous (1995), "Comparison of country of origin effects on household and organizational buyers' product perceptions," European Journal of Marketing, Vol. 29(3), 35-51.

Alba, J.W. \& J.W. Hutchinson (1987), "Dimensions of consumer expertise," Journal of Consumer Research, Vol. 13 (4), 411-455.
Alden, D.L., W.D. Hoyer \& A.E. Crowley (1993), "Country of origin, perceived risk \& evaluation strategy," Advances in Consumer Research, Vol. 20, 678-683.

Amine, L.S. \& S.H. Shin (2002), “A comparison of consumer nationality as a determinant of country of origin preferences," Multinational Business Review, Spring, 45-53.

Anderson, C.H. (1986), "Hierarchical moderated regression analysis: a useful tool for retail management decisions," Journal of Retailing, Vol. 62(2), 186-200.

Anderson, W.T. \& W.H. Cunningham (1972), "Gauging foreign product promotion," Journal of Advertising Research, Vol.12 (1), 29-34.

Andrews, J.C., S. Durvasula \& S.H. Akhter (1990), “A framework for conceptualizing and measuring the involvement construct in advertising research," Journal of Advertising, Vol. 19(4), 27-40.

Anholt, S. (2000), "The nation as brand," Across The Board, Nov/Dec, 22-27.

Arbuckle, J.L. (1999), Amos 4.0 programming reference guide, Chicago: Smallwaters.

Batra, R., V. Ramaswamy, D.L. Alden, J.B.E.M. Steenkamp \& S. Ramachander (2000), "Effect of brand local and non-local origin on consumer attitudes in developing countries," Journal of Consumer Psychology, 9(2), 83-95.

Bhuian, S.N. (1997), "Marketing cues and perceived quality: perceptions of Saudi consumers toward products of the US, Japan, Germany, Italy, UK and France," Journal of Quality Management, Vol. 2(2), 217-234.

Byrne, B.M. (2001), Structural equation modeling with AMOS: basic concepts, applications, and programming, Mahwah: Lawrence Erlbaum Associates.

Challagalla, G.N. \& T.A. Shervani (1996), "Dimensions and types of supervisory control: effect on salesperson performance and satisfaction," Journal of Marketing, 60(1), 89-105. 
Chao, P. \& K.N. Rajendran (1993), "Consumer profiles and perceptions: country of origin effects, "International Marketing Review, Vol. 10(2), 22-39.

Darling, J.R. \& F.B. Kraft (1981), "A competitive profile of products and associated marketing practices of selected European and non-European countries," European Journal of Marketing, Vol.11 (7), 519-531.

Dawar, N. \& P. Parker (1994), "Marketing universals: consumers' use of brand name, price, physical appearance, and retailer reputation as signal of product quality," Journal of Marketing, Vol.58 (April), 8195.

Eroglu, S.A. \& K.A. Machleit (1989), "Effects of individual and product-specific variables on utilizing country-of-origin as a product quality cue," International Marketing Review, Vol.6 (6), 27-41.

Elliott, G.R. \& R.C. Cameron (1994), "Consumer perception of product quality and the country-of-origin effect," Journal of International Marketing, Vol.2 (2), 49-62.

Hair, Jr., J.F., R.E. Anderson, R.L. Tatham, \& W.C. Black (1998), Multivariate data analysis, $5^{\text {th }}$ edition, Upper Saddle River: Prentice Hall.

Hair, J.F., Bush, R.P., and D.J. Ortinau (2000), Marketing research: a practical approach for the new millennium, Singapore: McGraw Hill.

Han, C.M. (1989), "Country image: halo or summary construct?" Journal of Marketing Research, Vol.26, 222-229.

Hansen, E. \& R.J. Bush (1999), "Understanding customer quality requirements: model and application," Industrial Marketing Management 28, 119-130.

Heimbach, A.E., J.K. Johansson \& D.L. MacLachlan (1989), "Product familiarity, information processing and country-oforigin cues," Advances in Consumer Research, Vol.16, 460-467.

Hooley, G.J. \& D. Shipley (1988), “A method for modeling consumer perceptions of country of origin," International Marketing Review, Autumn, 67-76.

Johansson, J.K. (1989), "Determinants and effects of the use of "made in" labels," International Marketing Review, Vol.6 (1), 47-58.

Kapferer, J.N. \& G. Laurent (1985), "Measuring consumer involvement profiles," Journal of Marketing Research, Vol. XXII, 41-53.

Kapferer, J.N. \& G. Laurent (1986), "Consumer involvement profiles: a new practical approach to consumer involvement," Journal of Advertising Research, Vol. 25(6), 48-56.

Kim, C.K. \& J.Y. Chung (1997), "Brand popularity, country image, and market share: An empirical study," Journal of International Business Studies, $2^{\text {nd }}$ Quarter, 361-386.

Kleppe, I.A., Iversen, N.M. \& I.G. Stensaker (2002), "Country images in marketing strategies: conceptual issues and an empirical Asian illustration," Brand Management, Vol. 10 (1), 61-74.

Kotler, P. (2003), Marketing management, $11^{\text {th }}$ edition, Upper Saddle River: Prentice Hall.

Lewis, E. (2002), "National pride and prejudice," Brand Strategy, June Edition, 20-22.

Luchs, B. (1990), "Quality as a strategic weapon: measuring relative quality, value, and market differentiation," European Business Journal, 2/4, 34-47.

Maheswaran, D. (1994), "Country of origin as a stereotype: effects of consumer expertise and attribute strength on product evaluation," Journal of Consumer Research, Vol.21, 354-365.

Malhorta (1996), Marketing research: an applied orientation, $2^{\text {nd }}$ edition, Upper Sadle River: Prentice Hall.

Manrai, L.A., D.N. Lascu \& A.K. Manrai (1988), "Interactive effects of country-ofOrigin and product category on product evaluation," International Business Review, 7, 591-615. 
Marks, L.J. \& Olson, J.C. (1981),"Toward a cognitive structure conceptualization of Product familiarity," Advances in Consumer Research, Vol.8 (1), 145-150.

Nagashima, A. (1970), “A comparison of Japanese and US attitudes toward foreign products," Journal of Marketing, Vol.34 (Jan), 68-74.

Nebenzahl, I.D., E.D. Jaffe \& S.I. Lampert (1997), "Towards a theory of country Image effect on product evaluation," Management International Review, Vol.37, 27-49.

Park, C.W., \& V.P. Lessig (1981), "Familiarity and its impact on consumer decision biases and heuristic," Journal of Consumer Research, Vol. 8(Sept), 223-230.

Peter, J.P. (1979), "Reliability: a review of psychometric basics and recent marketing practices," Journal of Marketing Research, Vol. XVI, 6-17.

Peterson, R.A. \& A.J.P. Jolibert (1995), “A meta analysis of country-of-origin effects," Journal of International Business Studies, Fourth Quarter, 883-900.

Phau, I \& G. Prendergast (2000), "Conceptualizing the country-of-origin of brand," Journal of Marketing Communication, Vol.6, 159-170.

Pisharodi, R.M. \& R. Parameswaran (1992), "Confirmatory factor analysis of a countryof-origin scale: initial results," Advances in Consumer Research, Vol.19, 706-714.

Rao, A.R. \& K.B. Monroe (1988), "The moderating effect of prior knowledge on cue utilization in product evaluations," Journal of Consumer Research, Vol.15 (Sept.), 253264.

Roth, M.S. \& J.B. Romeo (1992) "Matching product category and country image perceptions: a framework for managing country of origin effects," Journal of
International Business Studies, 23 (Third Quarter), 477-497.

Saunders, M., P. Lewis \& A. Thornhill (2000), Research methods for business students, $2^{\text {nd }}$ edition, Essex: Prentice Hall Financial Times.

Schaefer, A. (1997), "Consumer knowledge and country of origin effects," European Journal of Marketing, Vol. 31(1), 56-72.

Schellinck, D.A. (1983), "Cue choice as a function of time pressure and perceived risk," Advances in Consumer Research, 1983, Vol. 10(1), 470-475.

Thakor, M.V. \& L.P. Katsanis (1997), “A model of brand and country effects on quality dimensions: issues and implications," Journal of International Consumer Marketing, Vol.9 (3), 79-100.

Verlegh, P.W.J. \& J.B.E.M. Steenkamp (1999) "A review and meta analysis of country-oforigin research," Journal of Economic Psychology, 20, 521-546.

Zaichkowsky, J.L. (1985a), "Familiarity: product use, involvement or expertise," Advances in Consumer Research, Vol.12 (1), 296-299.

Zaichkowsky, J.L. (1985b), "Measuring the involvement construct," Journal of Consumer Research, Vol.12 (Dec), 341-352.

Zaichkowsky, J.L. (1986), "Conceptualizing involvement," Journal of Advertising, Vol.15 (2), 4-14.

(2012), "Samsung hits record high in global TV market share," What Hifi Online. Available at: http://www.whathifi.com/ news/samsung-hits-record-high-in-globaltv-market-share, accessed on May 28, 2013.

Dana, H. (2012), "Korean brands benefit from worldwide cultural exposure," Korean Net Online. Available at: http://www.korea.net/ NewsFocus/Society/view?articleId=100150, accessed May 12, 2013. 